\title{
Powder for Rectal Solution Dosage Form
}

National Cancer Institute

\section{Source}

National Cancer Institute. Powder for Rectal Solution Dosage Form. NCI Thesaurus. Code C149843.

Solid preparation consisting of one or more powders intended to be dissolved in the specified liquid to obtain a rectal solution. 